УДК 520.82

Віталій Петрович Спішев (канд. фіз.-мат. наук) ${ }^{l}$

Іван Іванович Мотрунич (канд. фіз.-мат. наук, с.н.с.) $)^{l}$

Василій Максимович Періг (м.н.с.) $)^{l}$

Віктор Ігорович Кудак (м.н.с.) $)^{l}$

Іван Федорович Найбауер

Петро Петрович Сухов (канд. фіз.-мат. наук, с.н.с.) $)^{2}$

Володимир Іванович Кашуба

Костянтин Петрович Сухов (м.нс.)

Ігор Давидович Варламов (канд. техн. наук)

Валентин Валентинович Албул

Сергій Станіславович Москаленко

Сергій Олександрович Мисливий ${ }^{4}$

${ }^{1}$ Держсавний вищий науковий заклад «Ужсгородський національний університет», Уэсгород, Украӥна ${ }^{2}$ Науково - дослідницький інститут "Астрономічна обсерваторія" Одеського національного університету ім. I.І. Мечникова, Одеса, Украӥна

${ }^{3}$ Національний університет оборони Украӥни ім. І. Черняховського, Київ, Украӥна

${ }^{4}$ Військова частина А0911, Київ, Украӥна

\title{
МОЖЛИВОСТІ НАЦІОНАЛЬНИХ ОПТИЧНИХ ЗАСОБІВ СПОСТЕРЕЖЕННЯ ЗА КОСМІЧНИМ ПРОСТОРОМ ЩОДО КОНТРОЛЮ ГЕОСТАЦІОНАРНОЇ ОРБІТИ У ІНТЕРЕСАХ ЗБРОЙНИХ СИЛ УКРАЇНИ
}

У статті представлені можливості національних наземних оптичних засобів спостереження за космічними об'єктами щчодо проведення комплексних оптичних спостережень космічних апаратів (КА) військового та подвійного призначення Російської Федераиї (РФ) у інтересах Збройних сил Украӥни $(3 С У)$.

До уваги надаються результати проведення колплексних спостережень геостаиіонарних КА військового та подвійного призначення РФ на прикладах багатоиільового військового розвідувального телекомунікаційного КА «Луч-Олімп» (2014-058A) та метеорологічного КА подвійного призначення «Электро - Л» №1 (2011-001A).

Комплексні оптичні спостереження космічних об'єктів у видимій частині геостаціонарної орбіти (дальній операційній стратегічній космічній зоні), дозволяють забезпечувати оперативний моніторинг військово-космічних систем розвідувального призначення, зв'язку, бойового управління та ретранслячії, раннього виявлення та попередження стартів ракет.

Комплексний аналіз, аналітична обробка та співставлення отриманих результатів спостережень космічних об’єктів у дальній операційній стратегічній космічній зоні з результатами моніторингу ближньої операційної стратегічної космічної зони, у якій застосовуються розвідувальні, навігаційні, топогеодезичні, метеорологічні та пілотовані системи, надає можливості щцодо формування комплексної картини оперативної обстановки (над територією України зокрема) та завчасного розкриття задуму противника.

Отримані актуальні дані дозволятимуть відповідним аналітичним підрозділам 3СУ, за демаскуючими ознаками та особливостями застосування КА та їх угрупувань, робити висновки щзодо ймовірних локачій (об'єктів, районів, напрямків) інтересу противника та ймовірних иңілей для систем та комплексів високоточного керованого ракетного озброєння.

Використання зазначеної інформацї у ЗСУ дозволить знизити втрати з боку особового складу, зберегти озброєння та військову техніку, завчасно визначати наміри противника, чим самим, в цілому, здійснювати більи ефективну протидію космічним системам противника.

Ключові слова: контроль космічного простору, аналіз космічної обстановки, космічний апарат, геостаціонарна орбіта, комплексні спостереження, фотометричні спостереження, позиційні спостереження.

Вступ

На даний момент, повноцінний контроль керованих, некерованих космічних апаратів (КА)

та об'єктів (КО), що знаходяться на

(C) В.П. Єпішев, П.П. Сухов, С.С. Москаленко, І.Д. Варламов та інш. 
геостаціонарній орбіті, здійснює виключно Російська Федерація (РФ) та Сполучені Штати Америки (США), які мають розвинену та розгалужену мережу пунктів радіолокаційного та оптико-електронного спостереження.

В Україні, для спостереження за КА та КО, що знаходяться на геостаціонарній орбіті, використовуються оптичні засоби спостереження.

Після розпаду СРСР, в Україні, оптичні спостереження за КО проводяться лише у кількох університетських обсерваторіях.

Зусиллями колективів національних обсерваторій, була збережена не тільки науковотехнічна база для проведення комплексних оптичних спостережень, а і були розроблені нові методи контролю за поведінкою КА на орбіті та виявлення характерних ознак їх цільового призначення.

Метою статті $\epsilon$ представлення можливостей національних оптичних засобів спостереження за космічним простором в частині проведення комплексних спостережень КА 3 метою визначення їх стану, складу бортової апаратури, просторової орієнтації та просторового положення на прикладі досліджень геостаціонарних КА РФ «Луч-Олімп» та «Електро-Л1».

\section{Аналіз можливостей проведення} комплексних спостережень КА. На даний час, в інтересах контролю космічного простору, а саме контролю КА, що знаходяться на геостаціонарній орбіті, в Україні працюють два пункти оптичних спостережень:

- Лабораторія космічних досліджень Державного вищого навчального закладу «Ужгородський національний Університет» (ЛКД ДВНЗ УжНУ);

- НДІ «Астрономічна обсерваторія» Одеського національного університету ім. I.I. Мечникова (НДІ АО ОНУ).

Програмно - апаратні комплекси обох пунктів оптичних спостережень дозволяють проводити регулярні високоточні позиційні та колориметричні (фільтри В, V, R) (комплексні) оптичні спостереження геостаціонарних КА у оптичному діапазоні хвиль.

Фахівцями зазначених пунктів оптичних спостережень проводяться роботи 3 розробки та вдосконалення програмного забезпечення та створення нових критеріїв ідентифікації КА.

Позиційні спостереження КА проводяться у екваторіальній системі координат, результати яких, за допомогою спеціального програмного забезпечення, перераховуються в геоцентричну та географічну системи координат 3 оцінкою добового дрейфу КА по орбіті та топоцентричні відстані до нього.
Апаратурний комплекс ЛКД ДВНЗ УжНУ складається 3 двох телескопів:

- «BRC-250M», діаметр дзеркала 250 мм., фокусна відстань 1268 мм. Телескоп призначений для проведення позиційних спостережень.

- «ChV-400», діаметр дзеркала 400 мм., фокусна відстань 1750 мм. Телескоп призначений для проведення фотометричних спостережень [7].

Апаратурний комплекс НДІ $\mathrm{AO}$ ОНУ складається 3 двох телескопів:

- телескоп схеми «Кассегрен», діаметр дзеркала 50 см., фокусна відстань 1200 см. Телескоп призначений для проведення фотометричних спостережень;

- телескоп системи «Аргунов-Фащевський», діаметр дзеркала 80 см., фокусна відстань 240 см. Телескоп призначений для проведення позиційних спостережень.

Приймачами випромінювання у першому телескопі $\epsilon$ фотоприймач «ФЕУ-79» 3 мультилужним фотокатодом, на основі якого працює фотометр - колориметр у режимі підрахунку імпульсів, у другому телескопі аналогом фотоприймача $є$ ПЗС - камера «ML9000».

Проникаюча здатність другого телескопу, досягає 19.5 зоряної величини за 30 секунд накопичення сигналу.

Обидва апаратних комплекси ЛКД ДВНЗ УжНУ та НДІ АО ОНУ дозволяють досягати роздільну здатність визначення орбітального положення геостаціонарних КО $\leq 1 " .0$, що у лінійних вимірах становить $\leq 180$ метрів.

Реєстрація блиску КА може відбуватися 3 експозицією від 0.1 сек. до 3 сек., що дозволяє визначати період коливальних або обертальних рухів КА $з$ точністю до $\pm 0,1$ сек.

Так само, апаратні комплекси пунктів спостереження, дозволяють проводити реєстрацію блиску КА у трьох спектральних смугах: В, V, R за міжнародною широкосмуговою фотометричною системою Джонсона [8].

\section{Виклад основного матеріалу дослідження.}

Дослідження КА «Луч-Олімп». КА РФ «Луч-Олімп», міжнародний номер 2014-058А, був виведений на геостаціонарну орбіту 28.09.2014

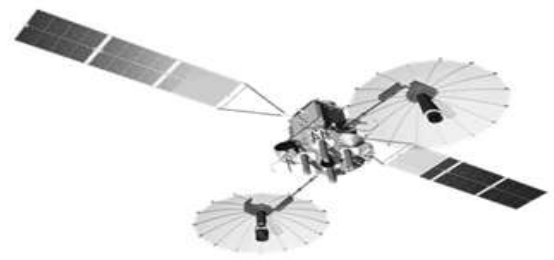

Рис.1. КА «Луч-5В» 
року в робочу орбітальну позицію $57^{\circ} \mathrm{E}$.

Окрім КА «Луч-Олімп», РФ має ще три КА зі складу системи «Луч-5».

Маса серійних КА «Луч-5» становить 1148 1350 кг.

Базова платформа для серійних КА «Луч-5» має назву «Експерсс-1000».

Основні орбітальні параметри і склад бортової апаратури КА наведені у відкритих джерелах [1].

На відміну від них, інформація по КА «ЛучОлімп» у відкритих джерелах дуже обмежена.

Повідомлялося про те, що КА «Луч-Олімп» виготовлений на підприємстві «Інформационные спутниковые системы» им. М.Ф. Решетнева»» за спільним замовленням ФСБ та МО РФ.

Відповідно до офіційних повідомлень виробника даного КА підкреслювалося, що його виготовлено також на базі платформи «Експрес$1000 »$.

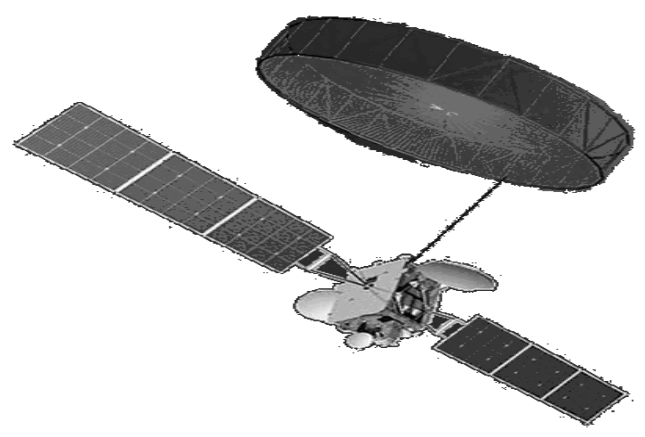

Рис.2. КА «Луч-Олимп»

Однак, у інших відкритих джерелах інформації, повідомлялося, що маса КА «ЛучОлімп» дещо більше ніж 3000 кг. Що звичайно не відповідає можливостям несучої платформи «Експрес-1000». Таким чином, для заявленої маси КА повинна використовуватися більш потужна супутникова платформа.

Неоднозначність даних була і про кількість радіоантен та інших складових бортової апаратури КА [3].

Інформація про те, що КА створений на новій елементній базі 3 використанням нових технічних та технологічних розробок у галузі електронної радіорозвідки та зв'язку, в черговий раз підтверджувала даний КА у військових цілях для потреб ФСБ та МО РФ.

За даними 3 відкритих джерел інформації, одна 3 антен КА «Луч-Олімп» призначена для персонального зв'язку особливої важливості [4].

Так само, є непрямі підтвердження про наявність на КА лазерно-радіотехнічних каналів зв'язку з низькоорбітальними розвідувальними КА, які проводять розвідку поза зонами прийому наземних служб РФ.

Робоча орбітальна позиція даного КА за повідомленнями, повинна була становити $167^{\circ}$ E.[2].

При цьому КА «Луч-Олімп» початково був виведений у точку стояння, що складала $57^{\circ} \mathrm{E}$.

Хронологія передислокацій КА «ЛучОлимп». Після виведення КА «Луч-Олімп» на геостаціонарну орбіту, КА одразу почав свій рух у східному напрямку.

7.жовтня.2014, КА досягнувши орбітальної позиції, що складала $52^{\circ} \mathrm{E}$, зупинився біля КА системи стратегічної РЕР Національного управління військово-космічної розвідки США, АНБ та ЦРУ «NROL-15» (USA237/Mentor/Advanced Orion та KA WGS-5 широкосмугового стратегічного зв'язку Департаменту оборони США.

Після трьох місяців перебування на орбітальній позиції у $52^{\circ} \mathrm{E}$, КА «Луч-Олімп» почав передислокацію у східному напрямку.

У березні - квітні 2015 року КА призупинився на довготам, що відповідали $95^{\circ}-96^{\circ} \mathrm{E}$, у зоні проведення активних маневрів кораблів Тихоокеанського флоту РФ.

У тій же орбітальній позиції, на той час, знаходився КА радіоелектронної розвідки США «Advanced Orion» (Mentor), який забезпечує даними ЦРУ та АНБ США.

Так само, з цієї орбітальної позиції, постійно проводяться перехоплення урядової i дипломатичної інформації, яка надходить від китайських спецслужб.

У квітні 2015 року, КА «Луч-Олімп», 3 досить низькою швидкістю почав рух на захід, 3 короткостроковою зупинкою над територією акваторії Атлантичного океану, у орбітальній позиції, що складала $18^{\circ}, 1 \mathrm{~W}$.

Так «співпало», що у той час, флагман Чорноморського флоту РФ, ракетний крейсер «Москва», приймав активну участь у російськоєгипетських навчаннях.

Після завершення навчань, у липні 2015 року, КА «Луч-Олімп» наблизився на небезпечну відстань до КА США «Intelsat-7» та «Intelsat 901», чим самим, викликавши занепокоєння у компанії «Intelsat».

Як реакція на такі дії, Пентагон направив Міністерству закордонних справ РФ офіційну ноту протесту [5].

Незабаром, КА «Луч-Олімп» наблизився до військового КА Великої Британії «Skynet-5C» та КА ВМФ США «MUOS-3», та ймовірно проводив перехоплення даних та інспекцію зазначених КА.

На початку вересня 2016 році, КА «Луч Олімп» був виявлений у орбітальній позиції, що становила $1^{\circ} .28 \mathrm{~W}, 3$ якої почав рух у східному напрямку.

Після зупинки, нова орбітальна позиція становила $9^{\circ} .75 \mathrm{E}$. 
Знову, «так сталося», що передислокація КА «співпала» практично одночасно з початком руху ударного угрупування ВМФ РФ на чолі 3 авіаносцем РФ «Адмірал Кузнєцов» у акваторію Середземного моря.

3 цього моменту почалась активізація військових дій РФ на території Сирійскої Арабської Республики (САР).

Зазначене ударне угрупування ВМФ РФ брало безпосередню участь у застосуванні крилатих ракет типу «Калібр» по цілям, що знаходились на території (САР).

Результати комплексних спостережень КА «Луч-Олимп». У результаті багаторічного моніторингу орбітального положення КА РФ «Луч-Олімп» було встановлено, що його переміщення по геостаціонарній орбіті, $з$ однієї точки стояння у іншу, то у західному то у східному напрямках, завжди корелюється із застосуванням РФ систем та комплексів високоточної ракетно-реактивної зброї та активізацією (ескалацією) подій у інспірованих «гарячих точках», у яких РФ бере безпосередню участь.

Приклади результатів позиційних спостережень КА «Луч - Олімп» надаються у таблиці 1.

У заглавній частині таблиці наводиться: назва пункту спостережень, координати пункту спостереження, рік, місяць, число та юліанська дата проведення спостережень, кількість КА, що спостерігались на зазначеному інтервалі часу.

У першій колонці таблиці наводиться: дата спостережень, у другій: час спостережень у всесвітній шкалі часу; у третій та четвертій колонці: екваторіальні координати КА, у п'ятій: час у частках години, у шостий: азимут КА, у сьомий: топоцентрична відстань до КА, у восьмій та дев'ятій: геоцентричні екваторіальні координати КА, у десятій: довгота підсупутникової точки КА.

Таблиия 1

Результати обчислень орбітального положення КА на фіксовані моменти часу

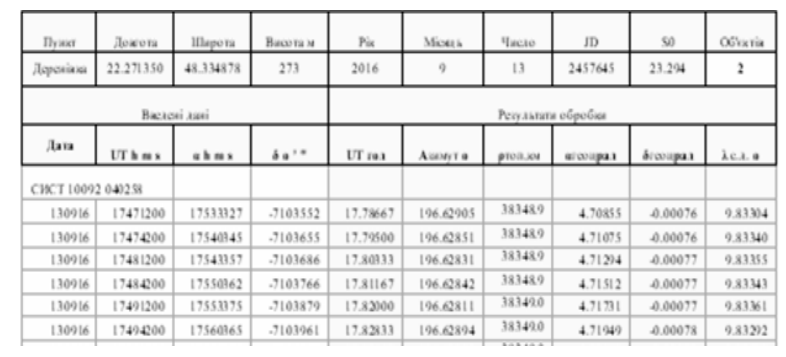

Для прикладу, у таблиці 1, наданий фрагмент результатів позиційних спостережень КА «ЛучОлімп» у ніч з 13.09.2016 на 14.09.2016 року, після його зупинки у орбітальній позиції, що становила $9^{\circ} .83 \mathrm{E}$.

Початок передислокації на зазначену точку стояння $\left(9^{\circ} .83 \mathrm{E}\right)$ було розпочато 30.08 .2016 року із середньою кутовою швидкістю, що становила 0,98 градусів за добу.
КА зупинився поряд 3 КА міжурядового зв'язку ЄC «EUTE W2C».

Точності, що досягаються при спостереженні, дозволили виявити не тільки зупинку КА, але i незначні зміщення та коливання вже безпосередньо у занятій орбітальній позиції, що говорило про те, що КА доводився до потрібних орбітальних параметрів.

Через кілька годин після доведення, КА наблизився до КА $\mathrm{CC}$ на $0.08^{\circ}$, що у лінійних вимірах становило близько 51 км.

Як раніше зазначалося, на той момент, підхід КА «Луч - Олімп» у точку стояння, що становила $9^{\circ} .83$, цілком збігся 3 входом авіаносця ВМФ РФ «Адмірал Кузнєцов» у акваторію Середземного моря.

У ніч на 27.07.2017 року, оптичними засобами спостереження було виявлено, що КА «ЛучОлімп» почав передислокацію у східному напрямку із середньою кутовою швидкістю, що становила 1,45 градусів за добу.

Графік руху КА «Луч Олімп» наведено на

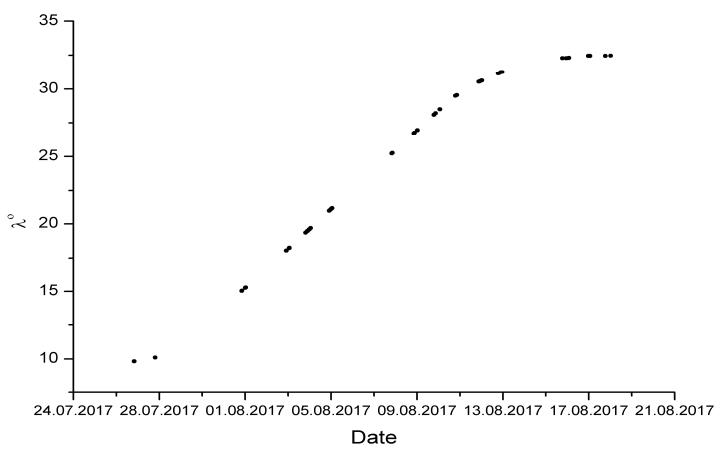

Рис. 3. Зміна довготи підсупутникової точки КА «Луч-Олимп» за период з 27.07.2017 по 17.08.2017.

Рис.3.

Аналіз отриманих даних показав, що КА «Луч-Олімп» виводився на максимальну швидкість переміщення поступово, практично протягом трьох діб.

Аналогічно відбувалося і його гальмування при наближенні до нової орбітальної позиції, що становила $32.47^{\circ}$.

У зазначеній орбітальній позиції, КА зупинився поблизу КА США «Intelsat NEWDWN».

Цей факт говорить про те, що КА «Луч Олімп» був керований на усьому етапі передислокації.

Фотометричні спостереження КА «ЛучОлімп» в залежності від умов спостережень проводилися в трьох, двох і одному фільтрах.

Станом на 27.09.2017, було записано 22 кривих зміни блиску КА «Луч - Олимп».

Для прикладу, на рис. 4, 5, надаються криві блиску КА «Луч-Олімп», що були отримані в результаті комплексних спостережень. 


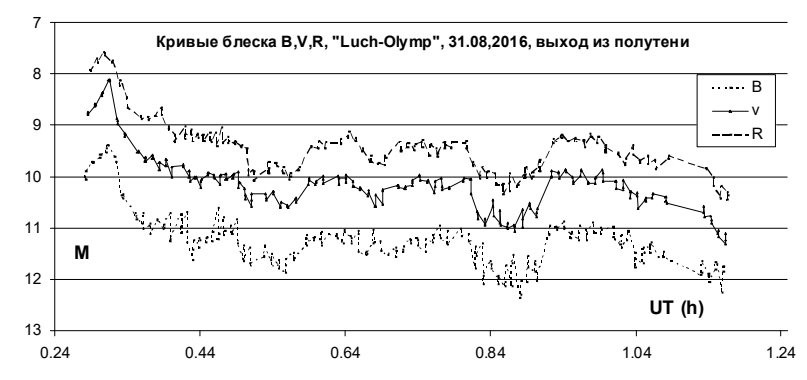

Рис.4. Криві блиску КА «Луч Олимп» фільтри B, V, R

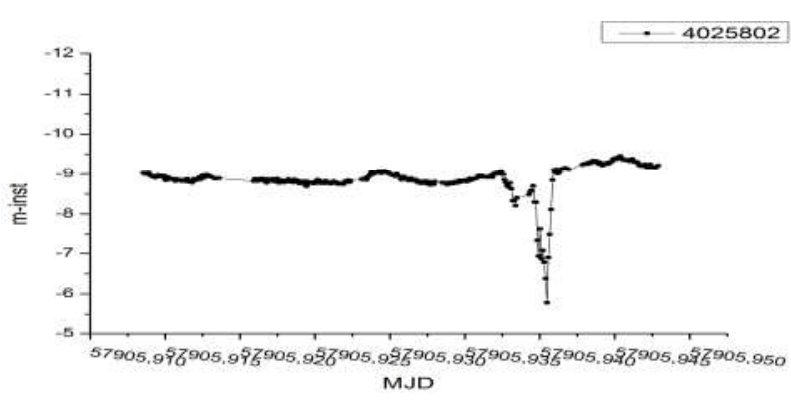

Рис.5. Крива блиску КА «Луч-Олимп» фильтр R

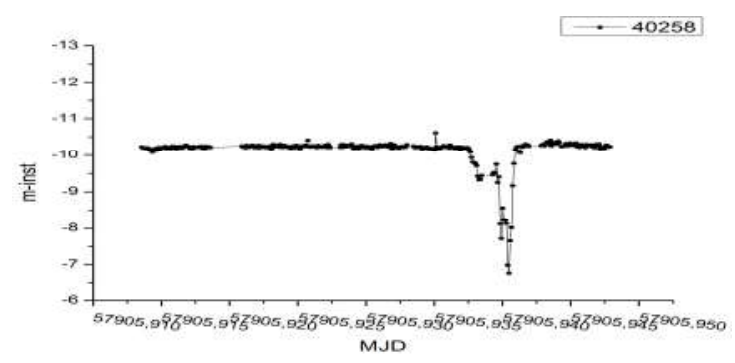

Рис.6. Крива блиску КА «ЕUTE W2C» фильтр R

Різке падіння блиску КА, що вказане на рис. 5 , викликане технічним збоєм у роботі фотометра.

Для порівняння, на рис.6, показана типова крива блиску KA «EUTE W2C» у фільтрі R.

Спостерігається, що блиск даного КА значно слабкіше за блиск КА «Луч-Олімп», тобто, це дві різні по конструкції платформи.

Інших змін блиску на відміну від КА «ЛучОлімп» у даного КА не спостерігалося.

Практично на усіх кривих зміни блиску КА «Луч-Олімп» на відміну від двох інших розглянутих КА, виявлена слабо помітна періодичність зміни блиску у 9,6 хвилини.

При наближенні КА, до місцевого меридіану спостерігачів 05.08.2017, у жовтому кольорі V, з'явилися слабкі дзеркальні спалахи, які повторювалися теж 3 періодом у 9,6 хвилин.

Виявлені зміни блиску КА, викликані скануючими коливаннями корпусу КА навколо власної вісі, яка збігається $з$ напрямком вектору руху КА по орбіті.

Завдяки виявленим коливанням, радіоантени КА мають можливість оглядати більш високі широти у північному та південному напрямках від екватора.

Такий принцип роботи мають КА стратегічного призначення США [8].

При наближенні КА «Луч Олімп» до місцевого меридіану, спостерігаємось внутрішньої поверхні параболічної радіоантени КА для українського спостерігача почала збільшуватися, що підтвердило зростання блиску КА у жовтому кольорі спектру та зменшення блиску у червоному кольорі.

У багатьох сучасних супутникових радіоантенах, внутрішня поверхня має золотистий колір, який біля зовнішньої сторони ближче до коричневого.

На довготі $32^{\circ} .3$ (центральний меридіан України), блиск КА у жовтому кольорі V, вже переважав над блиском у інших кольорах $(\mathrm{B}, \mathrm{R})$ (Рис. 7).

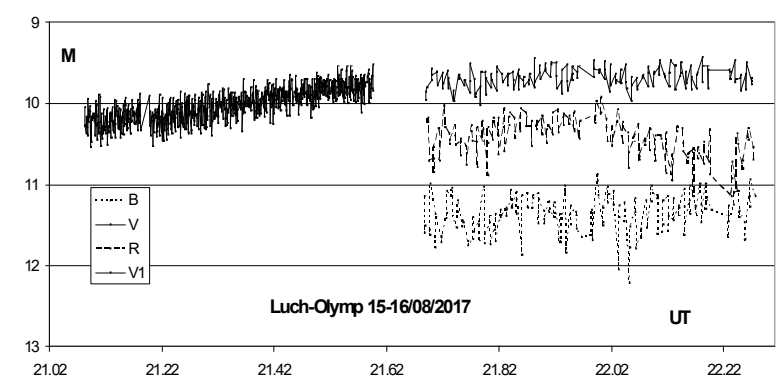

Рис.7. Криві блиску КА «Луч Олимп» фильтри В, R, V (15.08.2018)

Тобто, радіоантени КА «Луч Олімп» у другій половині серпня і у вересні були більш спрямовані у бік північних широт, як раз у напрямку - Кордон України - кордон Республіки Білорусь. Як раз у цій локації у той час и проводились спільні військові навчання РФ та Республіки Білорусь «Захід 2017».

Після завершення навчань «Захід 2017», блиск КА «Луч Олімп» у жовтому кольорі почав слабнути та зрівнявся 3 коричневим. Цей факт говорить про те, що радіоантени КА повернулися у початкове положення. Цикл спостережень КА «Луч Олімп» 15.08.2018.

На початку циклу, спостереження КА проводилися виключно у жовтому фільтрі V (ліва частина рис. 7).

Коли блиск КА «Луч Олімп» у цьому фільтрі досяг максимального значення, спостереження КА продовжилися у трьох фільтрах.

За результатами спостережень, відбивна здатність КА «Луч Олімп» у оптичному діапазоні, в цілому, невисока.

Коефіцієнти відбиття світла від основних фрагментів поверхні КА у всіх колірних каналах $€$ одними з найнижчих серед КА подібного класу. 
При вході - виході з тіні Землі, блиск КА «Луч-Олімп» збільшувався всього на дві зоряні величини.

Зазвичай, основна частка випромінення, що відбивається від конструктивних навісних елементів більшості КА приходиться на панелі сонячних батареї (ПСБ), які виготовлялися раніше на основі кремнію.

Максимум відбитого світла від сонячних панелей був у синій області спектру.

У випадку з КА «Луч-Олімп», блиск КА у синьому фільтрі найбільш слабкий, хоча розмах сонячних панелей досягає декількох десятків метрів.

Це говорить про те, що, швидше за все, панелі сонячних батарей КА «Луч Олімп» виготовлені на основі арсеніду галію, який добре поглинає і дуже слабо відбиває сонячне світло переважно у довгих хвилях.

Близькими до КА «Луч - Олімп» 3 подібними коефіцієнтами відбиття $є$ військові КА США класу «Ментор».

Практично усі КА, що знаходяться у захищеному секторі геостаціонарної орбіти, значно збільшують блиск при вході та виході з тіні Землі. Амплітуда збільшення блиску КА, що спостерігались раніше КА досягала п'яти і більше зоряних величин [9].

Так як, на даний час, достовірна інформація щодо реальних розмірів КА «Луч Олімп» невідома, для оціночних розрахунків використовувалися розміри типових КА, що виготовляються КБ ім. М. Решетнева.

Результати комплексних спостережень за геостаціонарним КА «Луч-Олімп» (2014-058А) дозволили зробити висновки, що переміщення КА по геостаціонарній орбіті завжди пов'язані із зміною глобальних зон, що представляють інтерес для військового та політичного керівництва РФ.

Багаторічні спостереження показали, що точки стояння значної часової тривалості КА «Луч-Олімп» поблизу геостаціонарних платформ США, НАТО, КНР завжди пов'язані з веденням радіоелектронної розвідки даних платформ та перехопленням радіосигналів під час пусків ракет - носіїв (РН) 3 навантаженнями військового призначення, випробуваннями балістичних ракет.

КА «Луч Олімп», протягом 2014 - 2017 років, здійснював переміщення уздовж геостаціонарної орбіти в обох напрямках;

3 початку активного застосування, КА «ЛучОлімп» багато разів змінював своє положення у поясі ГСО, рухаючись у обох напрямках у діапазоні довгот $24^{\circ}$ зах.д., $96^{\circ}$ сх.д. що підтверджує його активний та керований стан.

Аналіз швидкостей переміщень КА «ЛучОлімп» дозволив зробити наступні висновки:

- Повільні переміщення КА «Луч-Олімп» по геостаціонарній орбіті, його короткочасні паркування поряд іноземних розвідувальних КА пов'язані з проведенням їх інспекцій, що в цілому вказує на те, що КА «Луч - Олімп» $\epsilon$ багатофункціональним КА розвідки.

- Швидкі переміщення КА «Луч-Олімп» по геостаціонарній орбіті майже завжди пов'язані 3 проведенням стратегічних навчань Міністерства оборони Російської Федерації, бойовим застосуванням систем та комплексів високоточного керованого ракетного озброєння.

- Факти зближення або «паркування» КА «Луч-Олімп» поряд іноземних телекомунікаційних КА, зокрема через які орендуються (або можуть бути орендовані) урядові та військові лінії зв'язку та передачі даних дають підставу стверджувати, що КА «Луч - Олімп» проводить перехоплення урядових та військових ліній зв'язку та передачі даних.

- початок передислокацій КА «Луч Олімп» починається 3 переміщеннями i маневрами морських ударних угруповань ВМФ РФ;

- на платформі КА «Луч - Олімп» здійснюється випробування та відпрацювання нового типу електро-реактивної рухової установки, систем лазерної та лазернорадіотехнічного зв'язку, відпрацьовується технологія використання антен великого діаметру, що в свою чергу свідчить про відпрацювання нових технологій ведення стратегічної РЕР на геостаціонарній орбіті;

- КА «Луч Олімп» використовується $з$ метою наповнення (доповнення) існуючих баз сигнатур джерел радіо випромінювань, які наповнюються у результаті експлуатації КА РТР РФ типу «Лотос», «Целина» та розвідувальних авіаційних комплексів дальньої авіації МО РФ та ВТУ ГШ ЗС РФ;

- стратегічна РТР, що проводиться за допомогою КА «Луч Олимп», направлена на добування інформації стосовно розгортання на Європейському континенті нових підрозділів 3С країн НАТО. Основна мета РТР розвідки розкриття систем зв'язку та прихованого управління військами, виявлення та визначення координат важливих військових об'єктів за активністю радіо випромінювань, визначення ступенів бойової готовності та стану збройних сил іноземних держав, членів НАТО.

Дослідження КА «Электро-Л» №1. КА «Електро-Л» №1 був виведений на геостаціонарну

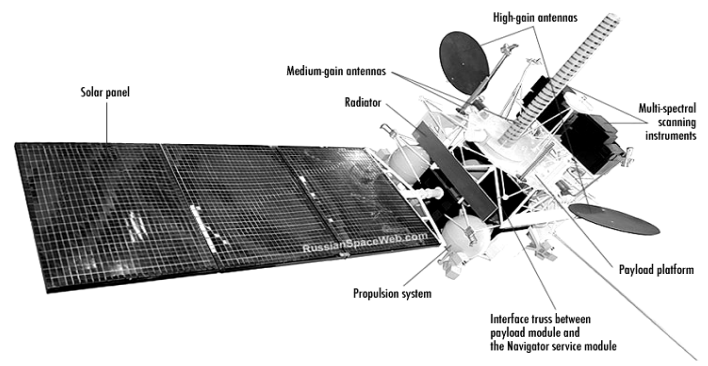

Рис.8. КА «Электро-Л» №1 
орбіту 21.01.2011 року на довготу стояння, у $54^{\circ} \mathrm{E}$, і згодом, був переведений на довготу стояння, у $76^{\circ}$ Е. Маса даного КА становить 1780 кг.

У відкритих джерелах інформації повідомлялося, що даний КА розроблений для потреб метеорології.

Протягом 10 років, КА «Електро-Л» №1 повинен був забезпечувати локальне та глобальне прогнозування погоди, проводити аналіз океанічних умов, а також моніторинг сонячної радіації, властивості іоносфери Землі та магнітного поля.

Хронологія передислокацій КА «ЭлектроЛ» №1. 3 липня 2016 року, через кілька місяців після виведення на навколоземну орбіту другого КА серії «Електро», КА «Електро-Л1» несподівано, почав передислокацію зі своєї робочої та, як зазначалось, довгострокової орбітальної позиції, що становила $76^{\circ} \mathrm{E}$ (акваторія Індійського океану) у західному напрямку.

Після здійснення серій маневрів, 03.10.2016, КА зупинився у орбітальній позиції, що становила $14^{\circ} .5 \mathrm{~W}$, поблизу від КА «Луч-5В» та трохи західніше від місця, де раніше знаходився КА «Луч-Олімп».

Причини передислокації КА «Електро-Л» №1 у точку стояння КА «Луч-5В» залишилися невідомими.

3 жовтня 2016, КА «Електро-Л» №1 зупинився у точці стояння, що становила $14^{\circ} .5 \mathrm{~W}$, однак через дві доби, почав обертатися навколо власної вісі, напрямок якої збігався 3 гравітаційною штангою КА та спіральною антеною (Рис.8).

Одночасно, КА почав неконтрольовано рухатись у західному напрямку, спочатку 3 кутовою швидкістю у 0,08 градусів за добу, а потім, з 0,10 градусів за добу.

Рух КА «Електро-Л» №1 по орбіті спостерігався національними оптичними засобами спостереження КА, поки не вийшов із зони досяжності засобів спостереження. Рух КА графічно відображено на рис.9.

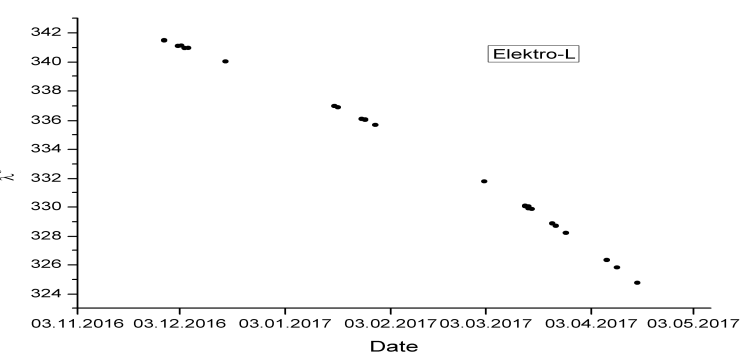

Рис.9. Зміна довготи підсупутникової

точки КА «Электро-Л» №1 за період 3 22.11.2016 по 17.04.2017

Спостерігалися неодноразові спроби зупинити обертання КА, але КА продовжував вільно обертатися та дрейфувати.
Результати комплексних спостережень КА КА «Електро-Л» №1. Комплексні спостереження аварійного КА «Електро-Л1» вдалося провести лише 03.12.2016, 06.12.2016 та 29.01.2017 року, причому, виключно у фільтрі R.

Результати спостережень за 06.12.2016 року надані на Рис.10.

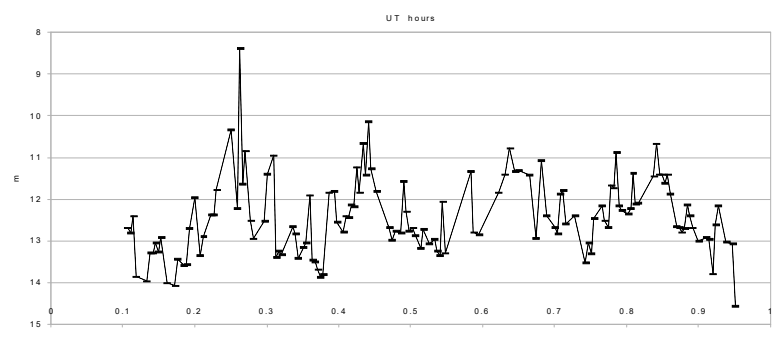

Рис.10. Крива блиску КА «Электро-Л1», фильтр R, (06.12.2016)

Під час спостережень виявлено збільшення періоду власного обертання КА за 57 діб. Період обертання збільшився з 11.3 до 17,3 хвилин.

На момент спостережень, вісь обертання КА здійснювала прецесійний рух навколо напрямку «зеніт-надир», з періодом у 150 хвилин.

12.04.2017, КА досяг довготи $34^{\circ} .18 \mathrm{~W}$, (узбережжі Бразилії). Подальші спостереження КА «Електро-Л1» були припинені у зв'язку із виходом КА із зони спостереження національних оптичних засобів.

Результати спостережень підтвердили, що КА «Електро-Л1», на момент спостережень, був дестабілізований та некеровано рухався по геостаціонарній орбіті.

Збільшення кута прецесії КА «Електро - Л», що спостерігалось, підтвердило факт повного переходу КА у некерований стан.

\section{Висновки й перспективи подальших досліджень}

Представлений матеріал показує можливості національних оптичних засобів спостереження по моніторингу геостаціонарної орбіти, що спостерігається 3 території України та спостереженню стратегічних військових космічних апаратів РТР, зв'язку, ретрансляції та цілевказівок 3 метою виявлення фактів маневрування (виявлення локацій інтересів противника), технічного стану, призначення i складу бортової апаратури.

Надані результати комплексних оптичних спостережень на прикладі спостереження геостаціонарних КА РФ «Луч-Олімп» та «ЕлектроЛ1».

Ділянка геостаціонарної орбіти, що спостерігається 3 території України перебуває у межах від $90^{\circ} \mathrm{E}$ по $36^{\circ} \mathrm{W}$.

3 огляду на існуючі можливості національних оптичних засобів спостереження за космічним простором, в умовах відсутності національних радіотехнічних засобів контролю геостаціонарної орбіти, можна констатувати факт, що на даний час, 
аппаратов (КА) Российской Федерации (РФ) военного и двойного назначения в интересах Вооруженных сил Украины (ВСУ).

К вниманию предоставляются результаты проведения комплексных наблюдений геостационарных КА РФ военного и двойного назначения на примерах многоцелевого военного разведывательного телекоммуникачионного КА «Луч-Олимп» (2014-058A) и метеорологического КА двойного назначения «Электро - Л» №1 (2011-001A).

Комплексные оптические наблюдения космических объектов которые находятся в видимой части геостационарной орбить (дальняя операционная стратегическая космическая зона), позволяют обеспечивать оперативный мониторинг военно-космических систем разведывательного назначения, связи, боевого управления и ретрансляции, раннего выявления и предупреждения стартов ракет.

Анализ, аналитическая обработка и сопоставление полученных результатов наблюдений космических объектов находящихся в дальней операционной стратегической космической зоне с результатами мониторинга КА находящихся в ближней операчионной стратегической космической зоне, в которой применяются разведывательные навигационные и топогеодезические, метеорологические и пилотируемые системь, предоставляет возможности по формированию комплексной картины оперативной обстановки (над территорией Украинь в частности) и заблаговременного раскрытия замыслов противника.

Полученные актуальные данные позволят соответствующим подразделениям ВСУ, по демаскирующим признакам и особенностям применения отдельных КА и их группировок, формировать выводы о возможных локаций (объектов, районов, направлений) интереса противника и вероятных иелей применения высокоточного вооружения противника и высокоточного управляемого ракетного вооружения.

Умелое и эффективное использование указанной актуальной информаџии в интересах ВСУ позволит снизить потери со стороны личного состава, сохранить вооружения и военной техники, заблаговременно определять намерения противника, чем же, в целом, осуществлять более эффективное противодействие врагу.

Ключевые слова: контроль космического пространства, анализ космической обстановки, космический аппарат, геостачионарная орбита, комплексные наблюдения, фотометрические наблюдения, позиционнье наблюдения.

\title{
THE OPPORTUNITIES OF NATIONAL GROUND-BASED OPTICAL SPACE SURVEILLANCE ASSETS FOR THE CONTROL OF THE GEOSTATIONARY ORBIT IN THE INTERESTS OF THE ARMED FORCES OF UKRAINE
}

Vitaly P. Yepishev (Candidat of Physical and Mathematical Sciences) ${ }^{1}$

Ivan I. Motrunich (Candidat of Physical and Mathematical Sciences) ${ }^{1}$

Vasil M. Perig (Junior Research Fellow) ${ }^{1}$

Victor I. Kudak (Junior Research Fellow) ${ }^{1}$

Ivan F. Nibauer ${ }^{1}$

Petro P. Sukhov (Candidat of Physical and Mathematical Sciences) ${ }^{2}$

Volodimir I. Kashuba (Research Fellow) ${ }^{2}$

Kostyantin P. Sukhov (Junior Research Fellow) ${ }^{2}$

Igor D. Varlamov (Candidat of Technical Sciences) ${ }^{3}$

Valentin $V$. Albul

Sergiy S. Moskalenko ${ }^{4}$

Sergiy O. Myslyvyy ${ }^{4}$

\author{
${ }^{1}$ State Higher Scientific Establishment «Uzhhorod National University», Uzhhorod, Ukraine \\ ${ }^{2}$ Scientific research institute «Astronomical Observatory» Odessa National University named after. I.I. Mechnikov, \\ Odessa, Ukraine \\ ${ }^{3}$ The National University of Defense of Ukraine named after I. Chernyakhovsky, Kyiv, Ukraine \\ ${ }^{4}$ The military unit A0911, Kyiv, Ukraine
}

The article presents the possibilities of the national ground-based optical space surveillance assets for the conduct of complex optical observations of military and dual-use purpose satellites of the Russian Federation in the interests of the Armed Forces of Ukraine.

The results of the complex observations of geostationary (GSO) military and dual-purpose satellites of the Russian Federation are illustrated by the examples of the "Luch-Olimp» (2014-058A) military reconnaissance multipurpose telecom satellite and the dual-purpose meteosat «Electro-L» №1 (2011-001A).

Carrying out of complex optical observations of space objects in the visible part of the GSO orbital belt (the far operational strategic space zone) provide operational monitoring of military-space systems of intelligence, communications, combat control and retransmission, early detection and warning of missile launches.

Comprehensive analysis, analytical processing and comparison of the results of observations of space objects in the far operational strategic space zone with the results of monitoring of the near operational strategic space zone in which reconnaissance, navigational, topogeodetic, meteorological and manned systems 
are used, provides opportunities for the formation of a comprehensive operational picture of situation (above the territory of Ukraine in particular) and the early disclosure of the enemy's plan.

The actual data received will allow the relevant analytical units of the Armed Forces of Ukraine, based on demagogic signs and peculiarities of the use of satellite and their clusters, to draw conclusions about the likely locations (objects, districts, directions) of the enemy's interest and the likely targets for the use of highprecision armament and missile-guided high-precision weapons.

Skillful and effective use of the above-mentioned actual information in the Armed Forces of Ukraine will allow to reduce personnel losses, to preserve weapons and military equipment, to determine in advance the intentions of the enemy, rather than, in general, to carry out more effective counteraction to the enemy.

Involvement of national optical observation assets for complex observations of the enemy's spacecraft and their clusters allows to provide effective monitoring of the operational environment in the near-Earth space in the interests of the Armed Forces of Ukraine.

Key words: space surveillance and monitoring, space environment analysis, satellite, geostationary orbit, comprehensive and targeted surveillance, photometric observations, positional observations.

\section{1.} References www.space.skyrocket.de/doc_sdat/luch-5b.htm 2. "Luch Olimp K“, available at: www.space.skyrocket.de/doc sdat/olimp-k.htm/ 3. "Dancing in the dark redux: Recent Russian rendezvous and proximity operations in space", available at: www.thespacereview.com/article/2839/2/ 4. "Russian Satellite Maneuvers, Silence Worry Intelsat", available at: bwww.spacenews.com/russian-satellite-maneuvers-silenceworry-intelsat// 5. "РФ змінить локацію свого єдиного авіаносця", available www.expres.ua/news/2016/09/22/204023-rf-zminytlokaciyu-svogo-yedynogo-avianoscya/ 6. "Elektro-L weather satellite", available at: www.russion spaceweb.com/elektro.html

7. Yepishev V.P. Astronomical observations in Uzhhorod, Derenovka point / Kudak V.I, Perig V.M., 7. 8, Yepishev V.P., Najbauer I.F. // International scientific and methodological conference KOLOS 2014. - 4.12-6.12. 2014. Slovakia. 8. Sukhov P.P. Results of complex studies of functioning in the orbit of the geosynchronous satellite «SBIRS-GEO-2»/ Sukhov P.P., Yepishev V.P., Sukhov K.P., Karpenko G.F., Mortunich I.I. // Space science and technology. Vol. 23 №1. 2017, p. 63-70. 9. Epishev V.P. On the advantages of photometric observations of the geostationary satellites at small phase angles / Sukhov P.P., Karpenko G.F., Sukhov K.P., Epishev V.P., Motrunych I.I., Kudzej I., Dubovsky P.А. // Одесса : Астропринт, 2014 . Vol.27, I. 1, P. 149-153 